\section{Universitetet i Oslo}

www.med.uio.no/disputaser/

Eivind Aakhus, ph.d. Tailored implementation for chronic diseases: depression in the elderly. Utgår fra Institutt for helse og samfunn. Disputas 22.2. 2017.

Bedømmelseskomité: Kristian Wahlbeck, National Institute for Health and Welfare, Mental Health and Substance Abuse Services, Helsinki, Finland, Mette Brekke, Institutt for helse og samfunn, Universitetet i Oslo, og Torleif Ruud, Institutt for klinisk medisin, Universitetet i Oslo.

Veileder: Signe Flottorp.

Mari Nerhus, ph.d. Migration and vitamin D in psychotic disorders a cross sectional study of clinical and cognitive correlates. Utgår fra Institutt for klinisk medisin. Disputas 3.3. 2017.

Bedømmelseskomité: Fiona Gaughran, Institute of Psychiatry, Psychology and Neuroscience, King's College, London, Storbritannia, Tore Sørlie, Institutt for klinisk medisin, Universitetet i Troms $\varnothing$ - Norges arktiske universitet, og Øyvind Rø, Enhet Voksenpsykiatri, Institutt for klinisk medisin, Universitetet i Oslo. Veiledere: Ingrid Melle, Akiah O. Berg og Ole A. Andreassen.

Marte Grønlie Cameron, ph.d. Palliative pelvic radiotherapy of symptomatic prostate and rectal cancers. Utgår fra Institutt for klinisk medisin. Disputas 3.3. 2017.

Bedømmelseskomité: Marie Fallon, Cancer Research UK Edinburgh Centre, MRC Institute of Genetics \& Molecular Medicine, University of Edinburgh, Storbritannia, Jan-Erik Frödin, Institutionen för onkologi-patologi, Karolinska Institutet, Stockholm, Sverige, og Stein Kaasa, Avdeling for kreftbehandling, Kreftklinikken, Institutt for klinisk medisin, Universitetet i Oslo.

Veiledere: Marianne Grønlie Guren, Christian Kersten, Ingvild Vistad og Sophie Dorothea Fosså.

Sture André Rognstad, ph.d. Inappropriate prescribing to older patients: criteria, prevalence, and an intervention to reduce it The Prescription Peer Academic Detailing (Rx-PAD) study. A cluster- randomized educational intervention in Norwegian general practice. Utgår fra Institutt for helse og samfunn. Disputas 3.3. 2017. Bedømmelseskomité: Susanna Wallerstedt, Institutionen för neurovetenskap och fysiologi, Göteborgs universitet, Sverige, Eivind Meland, Institutt for global medisin, Universitetet i Bergen, og Atle Fretheim, Institutt for helse og samfunn, Universitetet i Oslo. Veiledere: Jørund Straand, Mette Brekke og Arne Fetveit.

Monica Dahl Bjørge, ph.d. Impact of oxidative DNA damage repair on brain function. Utgår fra Institutt for klinisk medisin. Disputas 6.3. 2017.

Bedømmelseskomité: Margherita Bignami, Department of Environment and Primary Prevention, Instituto Superiore di Sant'a, Roma, Italia, loanna Sandvig, Institutt for nevromedisin og bevegelsesvitenskap, Norges teknisk-naturvitenskapelige universitet, og Jon Storm-Mathisen, Institutt for medisinske basalfag, Universitetet i Oslo.

Veiledere: Magnar Bjørås og Gunn Annette Hildrestrand.

\section{- NTNU}

Det skapende universitet

\section{http://www.ntnu.no/kalender\#tag=disputaserdmf}

Magnhild Singstad Høivik, ph.d. Early parent - child interaction problems in primary health care: screening, video-intervention and parental psychopathology. Utgår fra Regionalt kunnskapssenter for barn og unge (RKBU) Midt-Norge. Disputas 1.3. 2017.

Bedømmelseskomité: Anders Broberg, Göteborgs Universitet, Sverige, Sonja Heyerdal, Regionsenter for barn og unges psykiske helse, Helseregion Øst og Sør, og Norbert Skokauskas, Norges teknisk-naturvitenskapelige universitet. Veiledere: Turid Suzanne Berg-Nielsen og Stian Lydersen.

\title{
Arede Lægestand!
}

Medicinsk Paradeorchæster - her afbildet paa Aarets Generalphorsamling - ønsker at takke ærbødigst phor Studenterluerne som er blevet oss tilsendt et benaadiget i vaart Jubilæumsaar MMXVI. Som I kan se, ere det ikke længer kiøligt paa Studenternes Isser! Da Recrutteringen haver været recordstor de siste Semestere, ere vi lyksalige over at have mottaget mer end 30 Luer! Vi gaar Fremtiden i Møde i phuld et blanckpudset Uniphorm, med alle Giverne varmt paa Mindet!

Ærbødigst et Phorbindeligst

Hr. Phormand Åsne Granlund

Medicinsk Paradeorchæster

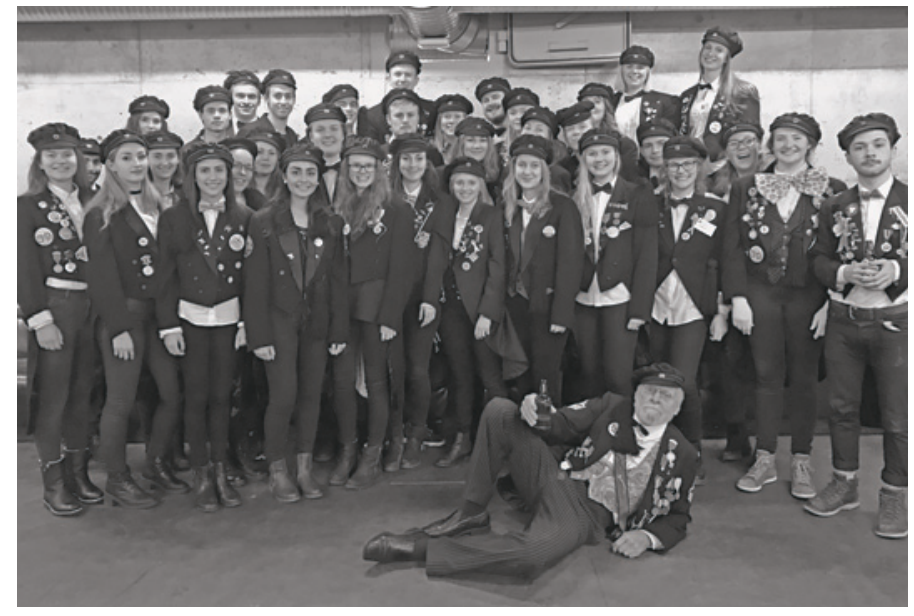

